\title{
Vascular Cell Adhesion Protein 1
}

National Cancer Institute

\section{Source}

National Cancer Institute. Vascular Cell Adhesion Protein 1. NCI Thesaurus. Code C48214.

Vascular cell adhesion protein 1 (739 aa, $>81 \mathrm{kDa}$ ) is encoded by the human VCAM1 gene. This protein is involved in the adhesion of immune cells. 